\title{
Self-Responsibility to Be Insured for the Future Social Risks Labor Contract and Social Insurance Rights (Albanian Case)
}

\author{
Behushi Pranvera, (PhD candidate) \\ National Business Center, Albania \\ Selita Mirela, PhD \\ Financial Supervisory Authority, Albania
}

\section{Doi: 10.19044/esj.2018.v14n8p94 URL:http://dx.doi.org/10.19044/esj.2018.v14n8p94}

\begin{abstract}
The right for social insurance is a right which derives from the labor relationships; so far, it is categorized into the group of private laws. The right for social insurance is a right for incomes when the employee cannot work because of sickness or labor accident or unemployment, or old age, invalidity, etc.

The aim of this study is to explore the relationship between self-responsibility and risk labor in Albania, from legal perspective. As social insurance right is an important part of the rights in the workplace, with this study we're going to identify the ways this articles dealing with the social insurance in Albania. This is a qualitative study and the data are generated from literature review. The analysis consists in a combination of the descriptive, comparative and analytical methodologies of the risks labor contract and social insurance rights.

As social insurances are closely related to the labor relationships, in Albania legislation body guarantie all the social insurance rights.
\end{abstract}

Keywords: Labor law, social insurance law, social rights

\section{Introduction}

In Albania, social insurance are closely related to the labor relations. The right for social insurance is an important part of the rights in the workplace. 
In the Labor Code $^{2}$ of the Republic of Albania there are lots of articles dealing with the social insurance rights arising from the labor relationship ${ }^{3}$. Those rights are related to labor accidents and professional diseases, special protection rules for women during, before and after childbirth ${ }^{4}$, etc.

The Albanian social insurance mandatory scheme covers all those individuals who earn their livings from their work as employed, self-employed or employers, and upon these incomes, they pay contributions in respect to sickness, maternity, work injuries, unemployment, pensions, etc.

Changes that occurred in the economic system in Albania in 1991, had an impact on social insurance system. The reform of the social insurance as part of social protection ${ }^{5}$ aimed at being in line with the requirements of a market economy. The reform started with the law no. 7703, date 11.05.1993 on social insurance, which entered into force on October 1, 1993.

The risks or needs that may give rise to social protection are fixed by International Labor Organization Convention as follows ${ }^{6}$ :

\begin{tabular}{ll} 
- & Sickness \\
- & Health care \\
- & Disability \\
- & Old age \\
- & Survivors \\
- & Unily/Children \\
\hline & Enemployment
\end{tabular}

Entitlement to social security, already mentioned in the labour clauses of the Treaty of Versailles on June 28, 1919, including the Constitution of International Labour Organization and in the Declaration of Philadelphia on May 10,1944, concerning the aims and objectives of the ILO, became a human right with the United Nations Universal Declaration of Human Rights on

\footnotetext{
${ }^{2}$ Labor Code of the Republic of Albania - Law nr.7961, date 12.07.1995 - Official Bulletin no.16/1995; amended by Law no.8085, date 13.03.1996 - Official Bulletin no.6/1996; Law no.9125, date 29.07.2003- Official Bulletin no.72/2003; Law no.10 053, date 29.12.2008 Official Bulletin no.205/2008; Law no. 136/2015, date 5.12.2015 - Centre for Official Publications of the Republic of Albania, web site www.qpz.gov.al

${ }^{3}$ Labor Code of the Republic of Albania, articles 39, 101, 104, 105, 105/a, 106, 107, 117 , $123 / 2,130,131,147,197 / 8$

${ }^{4}$ Prof. Kudret Çela “The labour law”, Tirana, 2003, "Ilar" Printing- House, ISBN 99927-8553-5, page 208

${ }^{5}$ Prof. Dr. Igor Tomes, "The Social Insurance Law", Tirana 1998. Prof. Dr. Igor Tomes, was the Consular for the Albanian Government, from the World Bank Project "Development of social protection schemes", starting in 1992

${ }^{6}$ ILO-International Labour Organisation Convention 102/1952

Law no. 9442, date 16.11.2005 "For the ratification of the ILO Convention no.102 "Minimum standard of social security"
} 
December 10, 1948 and the International Covenant on Economic, Social and Cultural Rights on December 16, $1966 .^{7}$

The various risks and needs define the primary purposes for which resources and benefits are provided, irrespective of legislative or institutional structures behind them. Individual entitlement to benefits is often based on contributions paid. There are also schemes, particularly those providing social assistance, which do not require the payment of contributions.

Contributory schemes are social protection schemes that require the payment of contributions, by the protected individuals or by other parties on their behalf, in order to secure individual entitlement to benefits. Contributory schemes are sometimes referred to as social insurance schemes.

\section{Methodology}

This is a qualitative study, exploring the workers self-responsibility according to social risks labor contract and social insurance rights. This study descript the definition of the basic concepts and elements of social security Albanian legislation, according to the objectives aimed at being achieved through such process as well as the factors that shape it. After the description of the above mentioned facts, through the comparative and analytical method, we have compared the Albanian legislation with the corresponding EU legislation. Afterwards the study continues with a totally analytical and critical method on the level of approximation of the Albanian legislation in the field.

Analysis and discussions of the data has been based in the respective regulative frame and narrative methods which has been considered "real world measures". This analysis is appropriate when "real life problems" are investigated, as this article aimed. One of the weaknesses of this narratives methods is that the text, mainly articles and laws is by its own nature linguistically subjective, as its difficult to quantitatively access in an objective manner since it is subjective meaningful.

\section{Analyses and Results}

\section{Labour relations in Albania}

The right of work is a fundamental right $^{8}$; it is an inherent warrant for economic and social security. The social objectives of the Constitution of the Republic of Albania provide that the government, by using its constitutional competencies and available means, as well as its attempts to carry out the initiative and private responsibility, aims at employment under favourable conditions for all individuals capable of working.

\footnotetext{
${ }^{7}$ Social Security as a human right. The protection afforded by the European Convention on Human Rights", Council of Europe, 2007 , ISBN 978-92-871-6261-8, printed at the Council of Europe, page 5

${ }^{8}$ The Constitution of the Republic of Albania, article 59
} 
Everyone has the right to freely choose his own job, e.i. his own subsistence through a decent work $^{9}$ fitting his capacities and abilities, qualification, gender, distance from the dwelling-place, etc. Labour relations are regulated by the Labour Code and sublegal acts. The legal acts are of two types: the classical and the professional ones, beginning with the classical act such as the Constitution, international conventions ratified by the Republic of Albania, the Labour Code, Council of Ministers decisions ${ }^{10}$, etc. Meanwhile, the professional acts (regarding labor relations) are collective labor agreements, individual labor contracts, internal regulations, local and professional customs (traditions). The relation between the employee and the employer, with the above-mentioned preconditions, are ultimately determined under a mutual juridical act, that is the Labor Contract ${ }^{11}$. The Labor Contract ${ }^{12}$ as a bilateral agreement requires mutual will. While, one party offers work and that is the employee (worker), the other party, that is the employer, offers renumeration for the work done. Like in all the other contracts, in the labor relation as well, it is to be determined the mutual liability duration terms or that the contract could be unlimited. The status of the parties, their rights and obligations represent an important part of the labor contract, but it is to be clarified that important and binding part of the labor contract regarding social insurance. The employee (worker) is protected and insured under social insurance $^{13}$, if they are sick, injuried at work, or has an occupational disease, or if they are unemployed, etc. The special protection of women during the labour relations and the obligations of the employer in that respect, are foreseen in the articles $104-108$ of the Labor Code. The latest amendments of the Labor Code were in December 2015, but they entered into force in June 2016. In July 2014, the law on social insurance was amended and the changes have been in force since January 2015. The amendments of social insurance law related to the maternity leave and other rights on that area were reflected in the labor code in 2015 when the code was amended. The Albanian labour legislation forces the employer to pay a minimum of $80 \%$ the wage or salary in case the employee is sick, because they can pay even more, and that means that payment is different, depending on the employers. Thus, it is clear that the 14 days of sickness prior to work, are not covered by social insurance. After 14 days, payment is made according to the social insurance law, the amount depends on the social insurance contributions paid out, and the latter are a

\footnotetext{
${ }^{9}$ International Labor Organization, topics "decent work"

${ }^{10}$ There are lots of Decisions of Council of Ministers, for instance DCM on minimum wage, etc.

${ }^{11}$ Labor Code, article 21 as amended by the laws no.8085/1996; no.9125/2003; no.136/2015

${ }^{12}$ Labor Code, article 12 as amended by the laws no.8085/1996; no.9125/2003; no.136/2015

Labor Code, article 21 as amended by the laws no.8085/1996; no.9125/2003; no.136/2015

${ }^{13}$ Law and Decision of Council of Ministers
} 
variable of the wage. ${ }^{14}$ Also, in order to avoid abuse and protect the employer, the code envisages the right of the employer that they can determine themselves a doctor to verify the sickness situation of the employee.

\section{Social insurance rights}

Everyone has the right to social insurance ${ }^{15}$ when retired or in case of incapacity of work under a certain system established by law ${ }^{16}$. Everyone, when unemployed for any reasons independent on individual will and when there is no living means, has the right of need under the conditions foreseen by law. The Constitution refers to the law of the Parliament; this is the legal reserve.

Compulsory social insurance scheme ${ }^{17}$, PAYG type system. The system was established on the principle of contribution, personal responsibility with respect to future risks in the social field and on intergeneration contract. It is a non-profit making scheme, protecting employees in respect to maternity, temporary incapacity due to sickness, occupational diseases \& employment, accidents, old age, disability, loss of breadwinner, and unemployment; other economically active individuals (employers and self-employed) in respect to maternity and old age, disability, loss of breadwinner. This scheme is financed out of contributions from employers, employed people, self-employed and state budget. Through these incomes (paid contributions), payment of benefits in cash is guaranteed at least for an amount that covers a minimum subsistence living standard, to be determined by Council of Ministers. Benefits are in any case guaranteed by the state budget.

The mandatory social insurance scheme protects the workers with short term benefits in case of temporary incapacity to work due to sickness, maternity, employment accidents/occupational diseases and unemployment and in case of permanent incapacity to work due to old age and disability.

\section{Short term benefits}

Cash sickness benefit. Medical report on temporary incapacity to work is delivered by the doctors where the sick person is registered. Such a doctor has the right to award 1 to 14 days of leave. The specialist doctor or dentist

\footnotetext{
${ }^{14}$ Labor Code, article 130 as amended by the laws no.9125/2003

${ }^{15}$ Article 52 of the Constitution of the Republic of Albania

${ }^{16}$ Law on social insurance no.7703, dated 11.05.1993, amended during the years

${ }^{17}$ Law on Social Insurance in the Republic of Albania no.7703, date 11.3.1993, amended by law no.7932, date 17.5.1995; law no.8286, date 16.2.1998; law no.8392, date 2.9.1998, law no.8575, date 3.2.2000; law no.8776, date 26.4.2001; law no.8852, date 27.12.2001; law no.8889, date 25.4.2002; law no.9058, date 20.3.2003, law no.9114, date 24.7.2003, law no.9377, date 21.4.2005, law no.9498, date 3.4.2006; law no.9600, date 27.7.2006; law no.9708, date 5.4.2007, law no.9768, date 9.7.2007, law no.10070, date 5.2.2009, law no.10447, date 14.7.2011, law no.104/2014
} 
has the right to give incapacity medical reports in all cases when a sick person is incapable to work and recommended to him by their doctor. Medical Expert Committee, based on the recommendation of the doctor who possesses the filling-card of the insured person, has the right to deliver a medical report of incapacity, as well as when such a person has spent the 14 days of leave.

Cash maternity benefit. ${ }^{18} \mathrm{~A}$ medical report ${ }^{19}$ in respect of pregnancy is given by the gynecologist doctor or the midwife when the former is absent. Women with more than one child in pregnancy benefit calendar days of medical report. Medical reports of 390 calendar days long, concerning after childbirth leave start on the day of childbirth. Such a report, for the first 60 days before and 63 days after childbirth, is delivered by gynecologist doctor at once, with separate 15-day reports, or midwife in case of his absence. After this term, the report is given by the doctor of the health institution where the personal filling-card is. In this case, the report is delivered monthly in separate 15-day intervals. After the confinement period or 63 days, women have the right to go on with the medical report regarding the after-childbirth leave. Child consulting centers treat mothers with medical reports with regard to after- childbirth leave, irrespective of her home in another centre, provided that she has consigned here the child's personal filling-card. Adoptive mother has the right to receive an after-childbirth leave starting on the day in which the adoption is done, excluding the first days that belong to the real mother. If the adoption is done within the period of after-childbirth leave, the adoptive mother shall profit the rest of days up to the day 330. If the insured woman changes the employment after a MEC $^{20}$ decision, because of pregnancy, she shall have the right to benefit maternity allowance to reimburse the loss of incomes caused by such an exchange, after she has spent the 14 days entitled by the health institution that possesses her personal filling-card.

The new social insurance law foresees the paternity leave; so far the child care is a benefit provided to mother or father of the child.

\section{Long term benefits \\ Invalidity}

Competent Medical Expert Committee decision determines the ability to work, both for physical or mental disabled people, the need for a permanent care of someone else. Person presents himself to the MEC solely on the checkup date to be determined by the social insurance general practitioner as well as on the re-examination date to be determined by the MEC. Rechecking up

\footnotetext{
${ }^{18}$ Article 13 of the law no.104/2014 "On some amendments on the Social Insurance Law no.7703, date 11.05.1993", Official Gazette no.137/2014

${ }^{19}$ Under the new law on social insurance the period after child birth is 63 days instead of 42 days which was in the past

${ }^{20}$ MEC - Medical Expert Committee
} 
the disabled by MEC for determining the ability to work shall depend on their health condition and must always occur two months before the deadline determined in the latest decision.

On reaching retirement age, the disabled pensioner shall have the right to opt for an old-age pension, if that shall be more favorable for him.

A disability pension shall be suspended for periods they refuse to visit the competent medical expert committee. It shall also be suspended when they refuse to participate in training/retraining courses or undergo medical rehabilitation or treatment against alcohol and drugs, which aim to retrieve their capacity for work.

\section{Old age}

The right to a pension shall not be forfeitable. The right to an individual monthly installment of a pension shall be forfeited in a year from the date of the commencement of a right. In other cases, the right to a monthly pension installment shall be forfeited from the date of claim submission. The acknowledged but not drawn pensions shall be paid any time, but only for three years. The rest of the pensions, which have been acknowledged, but less paid, shall be paid any time, but only for three years. The reimbursement of overpayments is requested to be done no later than three years from the execution, and no later than 6 months from the date those were verified. People benefiting through illegal means and manners, or not having informed on their change or abolition shall pay all sums back.

The current social insurance system also includes ${ }^{21}$ the social pension and the professional funds and the voluntary pension's fund ${ }^{22}$.

\section{Conclusion}

Social insurances in Albania are closely related to the labor relationships. The social insurance right is an important part of the rights in the workplace. In the Labor Code of the Republic of Albania there are lots of articles dealing with the social insurance rights arising from the labor relationship ${ }^{23}$. These rights are related to labor accidents \& professional diseases, special protection rules for women during, before and after childbirth, etc.

The right to social insurance is an important part of the corpus of rights arising from labor relations. Thus, by working and paying contributions, an

\footnotetext{
${ }^{21}$ The new pension`s reform in Albania and the law which is in force since January 1, 2015

${ }^{22}$ Article 1, article 5/1, article 5/2 of the law no.104/2014 "On some amendments on the Social Insurance Law no.7703, date 11.05.1993”, Official Gazette no.137/2014

${ }^{23}$ Labor Code of the Republic of Albania, articles 39, 101, 104, 105, 105/a, 106, 107, 117 , $123 / 2,130,131,147,197 / 8$
} 
individual takes responsibilities for the future risks, since a part of their incomes from work are saved for social insurance.

\section{References:}

1. Summary of the Albanian Social Insurance Legislation. (2010). Tirana: Centre for Official Publications of the Republic of Albania, ISBN 9789928-01-006-3

2. Çela, K. The labour law. (2003). Tirana: Ilar Printing-House, ISBN 99927-855-3-5

3. Anastasi, A. The constitutional law. (2004). Tirana: Pegi PrintingHouse, ISBN 99927-941-1-9

4. Xhumari, M. Pension Trajectories in Western Balkans. Three case studies: Albania, Macedonia and Kosovo 1990-2010. (2011). Tirana: Pegi Printing-House. ISBN 978-9928-124-24-1

5. http://www.qbz.gov.al/botime/sigurimet.html

6. http://www.ilo.org/global/standards/subjects-covered-byinternational-labour- standards/social-security/lang--en/index.htm

7. https://www.issa.int/en_GB/topics/understanding/introduction 